\title{
Critical external factors behind hotels' investments in innovation and technology in emerging urban destinations
}

\author{
JuAn Ignacio Pulido FERnÁndez \\ Department of Economics, University of Jaén, Campus de Las Lagunillas, s/n, 23071 Jaén, \\ Spain. E-mail: jipulido@ujaen.es. \\ ANTONia SÁEZ CALA \\ Department of Economic Structure and Development Economics, Autonomous University of \\ Madrid, Campus de Cantoblanco, 28049 Madrid, Spain. E-mail: antonia.saez@uam.es.
}

\section{CRISTINA FigueroA DOMECQ}

Department of Enterprise Economics, Rey Juan Carlos University, Paseo de los Artilleros, s/n, 28032 Vicálvaro, Madrid, Spain. E-mail: cristina.figueroa@urjc.es.

The decision-making processes of tourism firms are being conditioned by the profound transformations taking place in both client demand and destination dynamics. This new scenario requires an increased level of information, innovation and technology if tourism firms are to remain competitive. In particular, information and communication technologies (ICTs) can provide competitive advantages by improving a firm's knowledge of its own internal structures and of the milieu in which it is operating. This study therefore identifies and analyses the critical external factors that influence innovation and ICT investment in hotel businesses by evaluating the impact of hotel investment strategies. The methodological approach taken is an adaptation of the PESTEL model to the particular case of hotel management. This model identifies the factors (political, economic, social, environmental, technological and legal) that affect any given organization. The authors also apply Porter's 'five forces model', which assesses the competitive environment in which firms act, taking into account the power of buyers, intermediaries, current and potential competitors and substitutive products. The study area is the region of Madrid (MAC), since this has only lately emerged as a major tourist destination and its hotel market is recent and of medium to high quality.

Keywords: critical external factors; ICT; hospitality sector; innovation impacts; PESTEL model; Porter's five forces model 
In an increasingly competitive, global and changing environment, strategic management has become an essential area of knowledge. One of the most important and challenging subjects of research in strategic management, having to deal with different perspectives and propositions, is the identification and analysis of the factors that affect competition and business environments.

Traditional strategic theory emphasizes how important external elements are for any organization. It also identifies analysis of the external milieu as a crucial factor for an organization to take into account in its strategic decision making (Porter, 1996; Ellyard, 2006; Dwyer et al, 2009). Concepts and practices such as 'strategy as perspective' (Mintzberg, 1987) and 'contingent strategic perspective' (Porter, 1980, 1985, 1991) allow the company to analyse the external milieu together with an analysis of its own internal environment, thereby facilitating the implementation of strategies to identify and develop competitive advantages.

Various studies (Schmalense, 1985; Hansen and Wernerfelt, 1989; Rumelt et al, 1991; Roquebert et al, 1996; McGahan and Porter, 1997) have confirmed the importance of the external milieu to business performance, although they are not all in agreement on the scope of this factor. Indeed, the social interaction between organizations and their managers is now seen as a key element in allowing organizations to cope "with fast-changing environments and how new ideas, innovation and more significant strategic transformation come about' (Johnson and Scholes, 2002, p 23).

If an organization's external milieu is conceptualized territorially - that is, as a system of economic, socio-economic, cultural, political and institutional agents and elements with specific forms of organization and regulation and a dynamic of collective learning (Maillat and Perrin, 1992) - it can constitute a major and lasting source of competitive advantage. In that milieu, companies and other agents form networks of relationships and contacts of every type, establish bonds of cooperation and interdependence, use tangible and intangible resources and produce and exchange goods, services and knowledge. This organizational logic allows agents, and especially companies, to cooperate in innovation and competition, with innovation becoming a collective learning process (Aydalot, 1986).

Innovative activity is one of the aspects which most determine a firm's competitive position, and indeed is recognized generally as a major component of competitive advantage. From the territorial perspective, the phenomenon of creation and diffusion of innovation is based on the firm's relationships and interactions with its milieu.

The firm as a decisive element in the processes of creation and dissemination of knowledge is not an isolated innovative agent but an integral part of the local context. Hence, the type, density and quality of the relationships it engages in will be critical to the process of innovation. It will integrate better into its environment the closer and more continuous are its relationships and, on the contrary, will be integrated less fully if those relationships are merely occasional and dependent (Vázquez Barquero, 2002).

Innovative behaviour, as reflected in strategies of investment in innovation, depends on variables defined at a territorial level (local know-how, the qualifications of human resources, the existence of learning institutions that carry out $\mathrm{R} \& \mathrm{D})$. Firms' technological strategies and innovation processes are 
also conditioned by the sectoral context and its chain of values. Indeed, the latter determines the kind of innovation to introduce and the hierarchy of innovations and technology transfer, and the former generates major sectoral differences in opportunities, incentives, $\mathrm{R} \& \mathrm{D}$ investment and procedures from one industry to another. The result is that the characteristics of the innovation process change according to the type of productive activity (Vázquez Barquero et al, 1999).

Tourism as an economic activity is bound to a specific territory - the destination - which forms the basis for the management of innovative behaviour (Guía et al, 2006). Since it is a diverse sector, it is not surprising that there are marked intrasectoral differences in innovation. Moreover, there are also considerable spatial and temporal differences, even within the same subsector. This is because the drivers of innovation are time and place specific (Hall and Williams, 2008). For a tourism organization, an evaluation of the local milieu in which it operates will allow it to identify new opportunities and threats to take into account for effective management. Nevertheless, the increasing instability of today's competitive environment makes it important not only to forecast change, but also to acquire greater volumes of information on which to base those forecasts (Quinn, 1980; Camisón, 2000). Therefore, a crucial challenge is to develop tools of environmental analysis with the capacity to gather, classify and aid in evaluating relevant information, and which are adapted to specific operating sectors such as that of hotels.

By nature, information about the external milieu is complex, fuzzy and ambiguous (Simon and Namasivayam, 1999). This forces the firm to improve its analyses by applying technology to anticipate change and select the environmental variables which have most impact on its results. Furthermore, the implementation of modern information and communication technologies (ICTs) is contributing to a radical modification of the context in which tourism companies in general, and the hotel industry in particular, are competing.

The penetration of the Internet in households has led to a substantial improvement in the information available to customers (Victorino et al, 2005). It has led many of them to drop their brand loyalty and instead reward value for money in terms of quality (Olsen and Connolly, 2000). Consequently, in the case of hotels, the strategy of differentiation has become increasingly difficult. Instead, there is seen to be a need to focus on proactive change based on customer preference, quality and technology (Karmarkar, 2004). This implies that they must apply new, more technical, production models and improve their working methods.

Research on the process of ICT deployment and innovation in the hotel sector (Namasivayam et al, 2000; Wei et al, 2001; Sancho and Maset, 2002; Sancho, 2004) has found it to be influenced by factors of the external milieu. Variables such as increased competition in the hotel industry, the new characteristics and demands of their clients and the emergence of new technologies are seen as major factors stimulating investment in innovation and ICTs (Porter, 1991; Buhalis, 1998; Garrigós et al, 2004). Therefore, it is important for the sector to determine precisely which are these crucial factors of the external milieu, given their relevance in stimulating innovation and in defining innovation and ICT investment strategies. 
Business competition may be one of the best ways to stimulate innovation (Porter, 1980) but, in the case of hotels in Spain, high levels of competition are generally not conducive to innovation (Sancho and Maset, 2002). What is certain is that competition among hotel firms has altered the rules of the game. The existence of substitutes and the development of ICTs related to some of these products - such as videoconferencing and e-mail itself, which allow quick and easy contact and, in some cases, obviate the need for displacement (Garrigós and Narangajavana, 2002) - are affecting the design and implementation of ICTs in hotels and the diversification strategies of urban and business hotels.

The new client typology also affects which ICTs and innovations a hotel will implement, and hence its investment strategies (Victorino et al, 2005). Today's clients are ever more sophisticated and demanding. They are better informed, thanks to the Internet, a tool that not only gives them access to information on destinations, experiences, prices and availability, but also allows them to communicate their needs and desires in real time to providers (Buhalis, 2005). This greater customer power clearly benefits investment in innovation and ICTs, as has been the case of Madrid's hotels.

Finally, the emergence of new technologies applicable to the hotel sector has been vital in encouraging innovation and ICT investment (Namasivayam et al, 2000; Sigala, 2003; Sheldon, 2007). Indeed, together with the extension and personalization of the product portfolio, ICTs have become one of the key innovations in tourism and hotel activities (Siguaw, 2000; Buhalis and Licata, 2002; Sigala, 2003; ITH, 2007; Sheldon, 2007).

The technologies which have spread most rapidly in the hotel industry are those related to computing and the Internet (Namasivayam et al, 2000; Sancho and Maset, 2002). With their proven utility and effectiveness in other sectors, they were adopted readily, and then adapted, by hotels. Reservations by Internet, and e-mail and broadband Internet connection in hotel rooms, were implemented easily and resulted in an immediate improvement in quality and revenue, as well as adding a certain prestige to the hotel. The more slowly spreading technologies have been those related to the productive structure of the hotels themselves - 'yield and revenue management' (Y\&RM) - and ICTs of direct application to the hotel business. The reasons have been the lack of knowledge about them and the concomitant sparseness of their use, together with their high cost, since they have to be customized uniquely for each hotel. In sum, however, the continuing evolution in technological conditions has to be regarded as one of the factors influencing hotels' strategies of investment in innovation and ICTs.

Given this context, and based on an analysis of the impact of innovation and ICT investment strategies, the present work identifies and examines the critical external factors which influence those investments, considering the case of the hotel sector of an emergent urban tourist destination. The case study described is that of the Madrid Autonomous Community (MAC), considering its 3-, 4and 5-star hotels located in the municipalities of the region of more than 35,000 inhabitants and in operation before 2006. These municipalities boast meeting and convention centres, a wide-ranging cultural and entertainment offer and, above all, geographical proximity to the region's business and decision-making hubs. The hotels of the study represent $91 \%$ of all the region's hotels, $70 \%$ of its offer of places and $19 \%$ of is lodging establishments. They constitute the 
target group of the current strategy to improve the quality of hotels, which is being supported by various public administrations.

\section{Case study: the Madrid Autonomous Community}

In tourism terms, the Madrid Autonomous Community (MAC) is characterized as an emerging urban destination of great potential at the national level. The current rate of growth of the number of tourists and overnight stays is above the national average. In 2007 the growth rates of travellers and overnight stays were $7.7 \%$ and $6 \%$, respectively, compared to $3.1 \%$ and $1.7 \%$ for Spain overall (Instituto Nacional de Estadística, 2008). The region received a total of 9.3 million travellers, generating 17.5 million overnight stays in hotel accommodation, the average stay being 1.88 nights.

The MAC's tourism model is based on urban business and trade fair tourism, with a lower incidence of the seasonality typical of traditional coastal destinations, but with very brief stays in the hotels relative to the national average. In the past year this differentiating characteristic has been a strong point, as against the country's traditional tourist destinations, since it has avoided competition with them and has benefited from the growth in short breaks, the proliferation of low-cost companies and the growth of transactions by the Internet. For some years there has been an effort to move towards greater diversification, and the expansion of complementary leisure and tourism activities could become one of the keys differentiating the MAC from its competing destinations in business tourism.

The city of Madrid is the region's tourist destination par excellence. Indeed, it is one of Europe's preferential destinations for the organization of events and conferences due to its excellent combination of business infrastructure and tourist attractions. In 2007, it received more than 7 million tourists, ranking first among Spanish cities in this sense. Non-resident tourism rose by more than $11 \%$, with the principal source markets being the USA, the UK and Italy, with the latter continuing to grow.

The hotel base of the MAC is new and the result of regeneration. That half of the establishments were built in or after 2000, and only $11 \%$ before 1960 , is evidence of the considerable innovative effort being made by the hotel sector, together with quality (Figueroa et al, 2009). In this last regard, $57 \%$ of the hotels implemented quality control systems during the 1990 s and $32 \%$ from 2000 on. These have been mostly internal quality controls carried out by the chains themselves. For the outside world, however, they need to improve the visibility of their quality, since only a small fraction (2.5\%) have the ISO 9001:2000 rating.

In the period 2000-2005, 90\% of Madrid's hotels introduced process and product innovations. The superior categories showed a greater tendency towards process innovations, given their need to differentiate themselves and improve internal management and revenue, due to increased destination competition. This was most evident in chain hotels with their requirement of centralizing procedures and connectivity.

Productivity improvements and product portfolio expansion were the respective triggers for process and product innovations, as they also had been 
in the case of vacation hotels in Spain (Jacob and Bravo, 2001; Marín and Marín, 2002) and the USA (Namasivayam et al, 2000; Sahadev and Islam, 2005). But the impact of this innovative process has not been as significant as expected. There has been improvement in the quality of service, but not in productivity and revenue. Also, the probable relationship between innovative effort and intensity of the impact is independent of such variables as the type of hotel ownership.

\section{Methods}

The market environment of hotels located in the MAC was studied by means of an exploratory analysis, using the theoretical framework of strategic management since it has the tools required to facilitate analysis of the macroand microenvironments.

For analysis of the macroenvironment we use the PESTEL model, which allows identification of the political, economic, technological and legal aspects influencing business activities. PESTEL has become a widely used tool in business strategic analysis. It was first used by Aguilar (1967) under the denomination ETPS (economic-technical-political-social). Shortly afterwards, Arnold Brown of the Institute of Life Insurance proposed STEP (strategic trend evaluation process) to analyse the same factors, which later underwent a modification with the creation of STEPE (adding the ecological factor to the original four). In the 1980s such workers as Fahey, Narayanan, Morrison, Renfro, Boucher, La Meca and Porter made its use popular, while adding to and/or modifying the initial factors to analyse, thus generating PEST, PESTLE, STEEPLE, etc. All these variations of the basic model allow one to evaluate the external environment in which an entity operates, permitting the identification and understanding of the risks associated with the growth or decline of the market which can affect the situation, capacity and management of an organization at any given time. This analysis assists the entity in gaining an optimal strategic position by maximizing the benefits brought about by market opportunities and minimizing the threats. Although it does not involve exhaustive research, it does allow the visualization of structural trends or forces that can affect a particular activity significantly.

However, the unmodified model is unsuitable for analysis of the environment affecting hotels, as it does not include other basic variables needed to understand this market. For the present study, therefore, we took as the basis the work of Monfort (2000) and Figuerola (2006) to generate an adaptation of the model for the general hotel environment, which we called PESTELIR (see Table 1). In this model, political, economic, socio-demographic, technological, ecological and legal factors are analysed (although the initial design of PESTELIR separated political and legal conditions, they were merged into one category for the definitive version because, as pointed out by the experts questioned in the pre-test, their conceptions were similar). Added to these are infrastructure and human resource conditions. In the latter category, such factors as the availability of training within the environment in the form of business and learning centres tailored to the sector have been identified as capable of attracting skilled personnel. The foregoing factors are fundamental in order to 
Table 1. The PESTELIR model.

Political conditions

- Regional and local policies supporting website development

- Public subsidies for ICT implementation

- Tourism promotion

\section{Socio-demographic conditions}

- Changes in consumption habits

- New customer needs

- New market segments

Ecological conditions

- Pollution

- Environmental policies regulating protected areas

\section{Infrastructure conditions}

- Changes in tourism infrastructure (airports, convention centres)

- New communication infrastructures (for instance: digital terrestrial television [DTT], wider geographical coverage of broadband Internet access)
Economic conditions

- Macro- and microeconomic trends determining business investments: economic cycles.

- Changing origins of most tourists

- Development of new destinations

\section{Technological conditions}

- Technology-related innovations allowing the offer of new hotel products and services or improvements in productive processes

\section{Legal conditions}

- Legislation regarding construction

- Legislation for protection of personal data

\section{Human resource conditions}

- Basic features of the workforce to be accessed by hotels and other tourism organizations: training, motivation, languages

attract tourists to a particular destination, and foster the creation of a business environment that encourages hotels to invest.

For evaluation of the microenvironment we used Michael Porter's five forces framework (5FF), which examines the competition in the market in which a specific business operates, and thus forms the basis for evidence-based decisions on which actions to take (Grundy, 2006). This analytical framework permits one to identify the basic characteristics of the different organizations that operate in the market, the existence of entry barriers allowing or impeding the threat of new entrants, customers' and suppliers' bargaining power and the threat of substitute products with the potential to modify consumption habits, given that they provide features similar to those of the replaced products. Since this model is fully adaptable to any environment (Johnson and Scholes, 2002), it needed no modification for use in analysis of the MAC's hotel environment.

With these two environment analysis models adapted to hotel activities (PESTELIR and 5FF), we drafted a survey instrument to collect information from a selected board of experts on the use of ICTs in the hotel sector. The format of the instrument was semi-structured to facilitate the tasks of qualitative analysis. It was presented as an Excel spreadsheet to send by e-mail. The board of experts consisted of 39 persons, representing the main institutions, agencies and Spanish business associations with connections to the field of hotel 


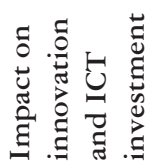

do

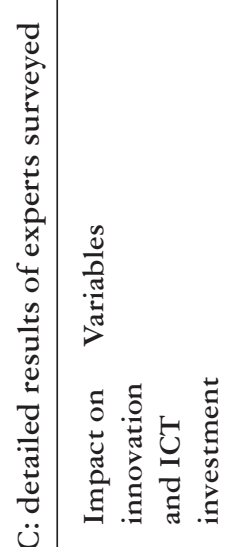

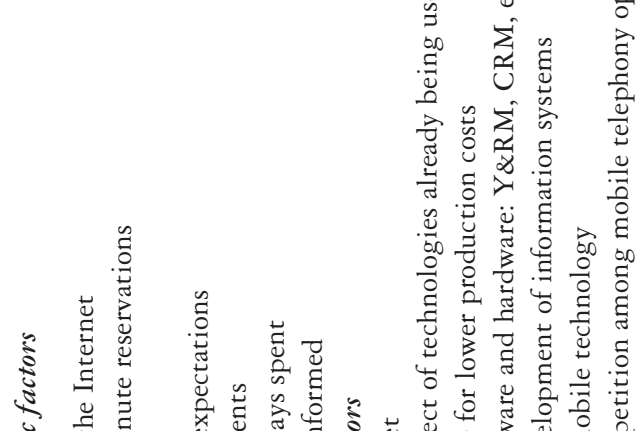

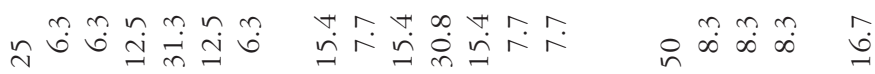

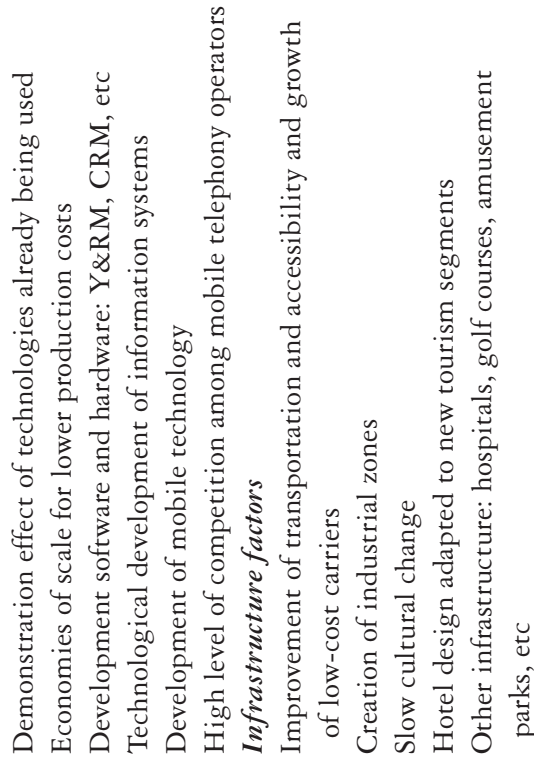

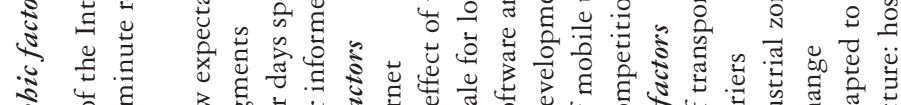

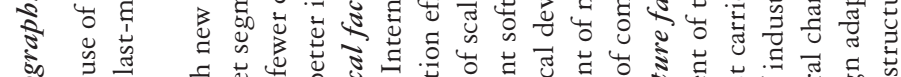

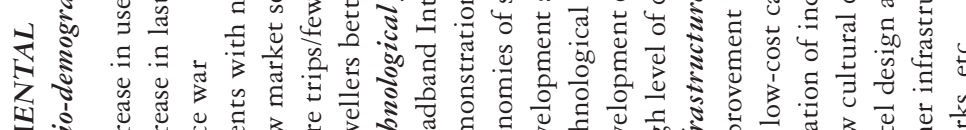

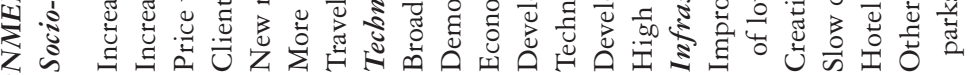
8

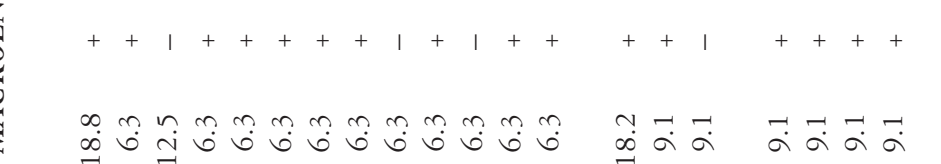

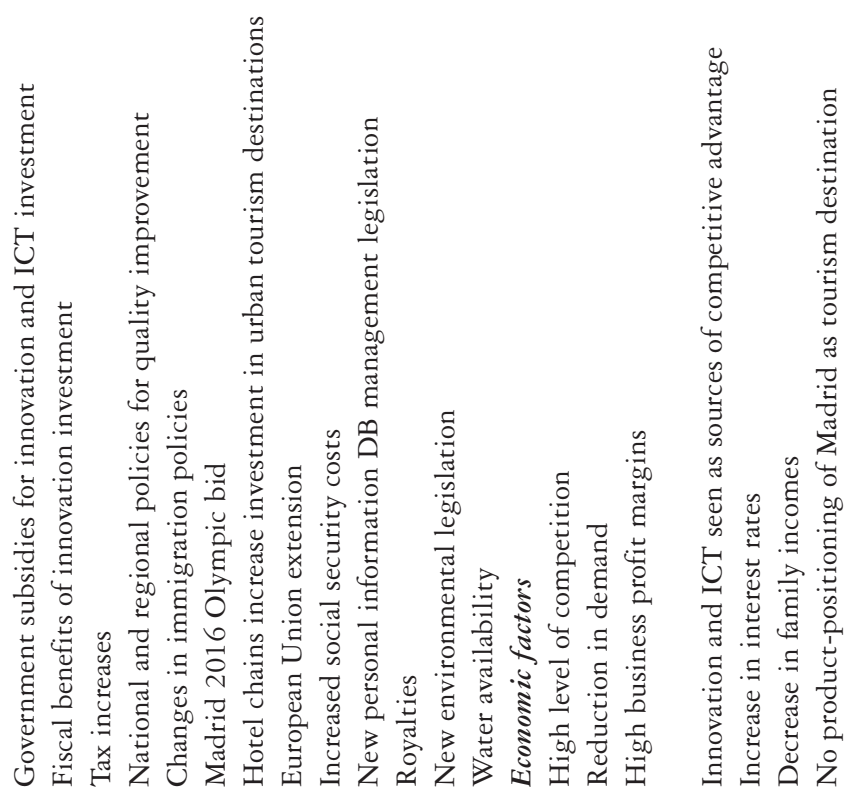




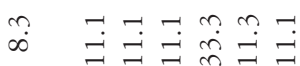

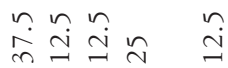

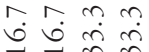

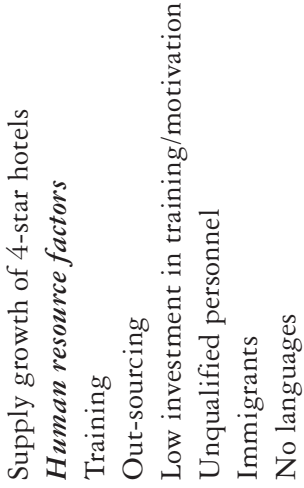

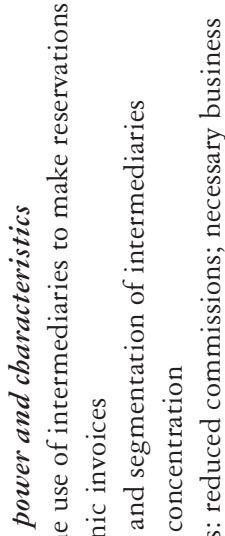

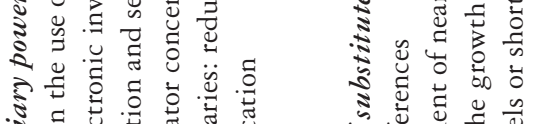

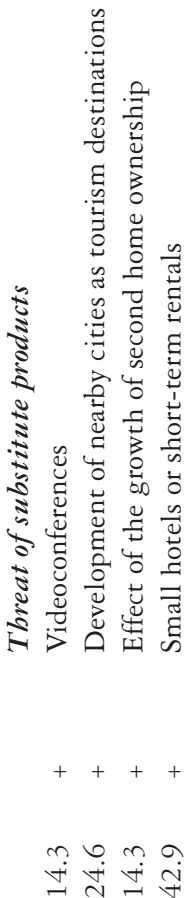

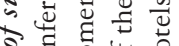

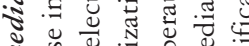

$\div$ 苛㟧

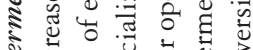

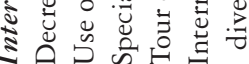

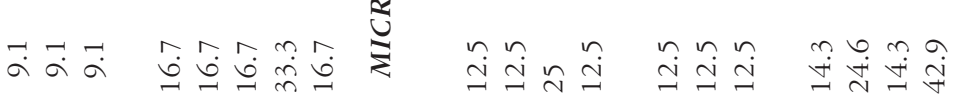
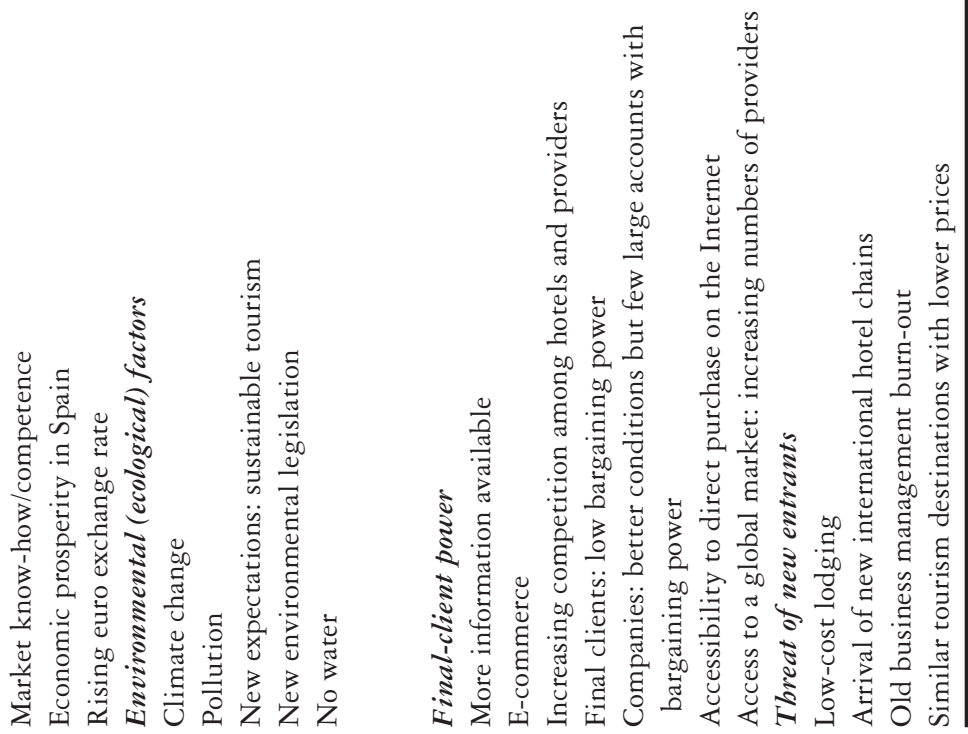
management (for example, the Spanish Confederation of Hotels and Tourist Accommodation - CEHAT, the Hotel Technology Institute - ITH and the Spanish Institute for Tourism Quality - ICTE), professionals of recognized hotel chains in Spain (for example, the Paradors of Tourism, Sol Meliá, Barceló Hotels and Resorts, Occidental Hotels, Husa Hotels Group, NH Hotels, Hotels Hesperia and Vincci Hotels), consultants in tourism administration and researchers with proven experience in the hotel management field from different Spanish universities (Universidad Europea de Madrid, Universidad Rey Juan Carlos, Universidad de Valencia, Universidad de las Islas Baleares and Universidad de Málaga) and the Spanish Association of Scientific Experts in Tourism - AECIT.

The questionnaire was drafted on the basis of a review of the literature on innovation and ICT investment related to tourism worldwide, and was validated by means of a pre-test presented to a significant selected subset of the experts, who were interviewed afterwards. The questionnaire divided the environmental analysis into general and specific questions, requesting the participants to indicate the main factors at the national and the MAC level which in the period 2000-2005 had either stimulated or discouraged innovation or investment in innovation and ICTs in 3-, 4- and 5-star hotels in the MAC.

In order to collect as much information as possible and to avoid a priori interfering with or conditioning the invited experts' responses, it was decided to design an open format questionnaire. In this, for each of the major groups of factors to consider - both macro- and microenvironmental - the respondents were asked to identify (up to a maximum of five) those they considered most influential in each case. The responses of this first round were homogenized, and then we selected those that presented the greatest level of consensus among the respondents. These were used to redesign the questionnaire, now including the closed items as presented in Table 2 .

The data of this final questionnaire were analysed using the SPSS statistical package, identifying which general and specific variables pertaining to the milieu of the sector had the greatest impact on the innovation and ICT investment decisions of the hotels located in the MAC.

\section{Results and discussion}

The results (Figures 1 and 2, Table 2) show that investment decisions in the tourist sector are, indeed, affected by many environmental factors. In particular, the more global and competitive environment stimulates organizations that intend to remain competitive to invest in innovation and ICTs. These investments are seen as essential in order to respond efficiently to the new consumption habits and needs of tourists. However, a note of caution must also be sounded since the results also show that it is not all advantages surrounding the hotel sector.

One observes (Figure 1) that hotel innovation and ICT investment is stimulated mainly by the macroenvironment. The exception is the influence of the characteristics of the human resources in the MAC, since most of the experts $(67.7 \%)$ consider that these act as a negative environmental factor. In general, however, most of the macroenvironment factors analysed had a significant positive influence on hotels' innovation and ICT investment, with the most 


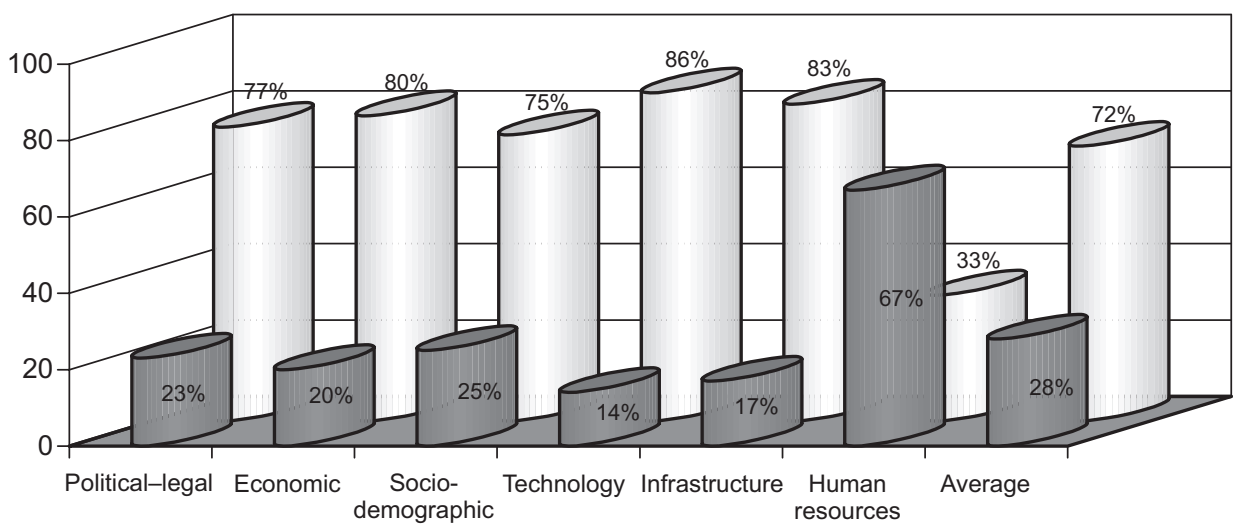

$\square$ Negative $\quad \square$ Positive

Figure 1. Macroenvironmental analysis of the MAC: overall results of the experts surveyed.

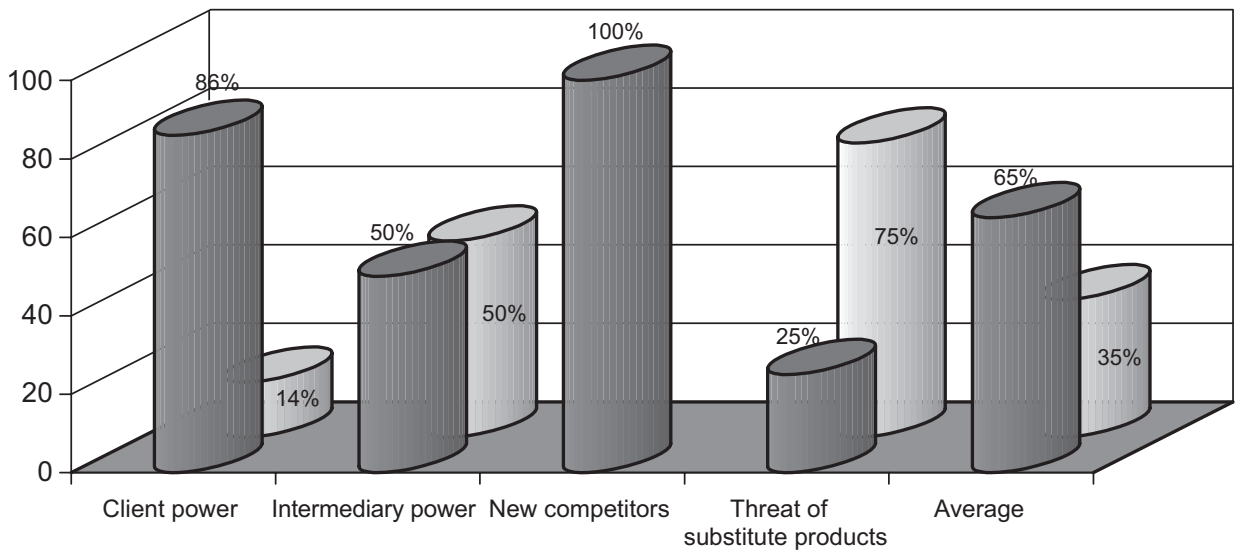

Positive $\square$ Negative

Figure 2. Microenvironmental analysis of the MAC: overall results of the experts surveyed.

influential being the technology-related (85.7\%), infrastructure (83.3\%) and economic $(80 \%)$ factors.

The microenvironment was not seen as stimulating innovation and ICT investment as markedly as the macroenvironment (Figure 2). The average proportion of the board of experts valuing the influence of microenvironment factors as fostering innovation and ICT investment was $65.2 \%$, as opposed to the $72.5 \%$ for the macroenvironment factors. Although increased competition seems to stimulate innovation and technology investment, when it is extremely 
high, the constraints it generates can diminish revenues in certain geographic locations, and hence lead to aversion towards innovations.

The analysis of the microenvironmental competitive forces (Figure 2) indicates clearly that increased customer power benefits innovation and ICT investment $(85.7 \%)$, as also does the threat of new entrants (100\%). This latter stimulates hotel organizations to implement differentiation strategies before these new entrants actually arrive. The suppliers' bargaining power has both positive and negative aspects, and the threat of substitute products is a clearly negative factor $(75 \%)$ as it entails a change in customers' needs, which are difficult to address even with the use of innovation and ICT.

Indeed, the evolution of some forms of lodging, such as the case of tourism apartments, threatens to generate evident substitutive products for hotel accommodation in the MAC. In Spain overall in 2007 there were 103,594 such apartments, nearly 10,000 fewer than in 2000. But in the MAC the case has been the contrary, with an increase in the number of these apartments from 2,105 to 2,235 in the period 2000-2007. Despite this increase, occupancy rates have remained stable $(72 \%)$, while in the rest of Spain there has been a steady decline of more than $10 \%$ from the $69 \%$ occupancy in 2000. Furthermore, in the MAC there is a fairly evenly distributed use of this type of accommodation between residents and non-residents $(54.2 \%$ and $45.8 \%$, respectively), while for the rest of Spain by far the most frequent users are non-residents $(76.5 \%)$ rather than residents $(24.4 \%)$. Consequently, it is clear that tourism apartments have found a good niche in which to grow in the Madrid market and have become true competitors to hotels.

\section{Macroenvironment}

For these hotels, increased competition is the most influential economic factor stimulating investment in innovation and ICT. This increase in competition is due mainly to growth in hotel supply $(18.2 \%$ of the responses referred to this specifically). In any case, the market's general opinion is that innovation and ICT are means with which to achieve competitive advantage (9.1\%). On the contrary, factors seen as having a negative influence on sustaining hotel growth and investment, causing financing to be diverted to other projects, are euro appreciation $(9.1 \%)$ and high commercial margins in other sectors $(9.1 \%)$.

Changes in consumption habits and the new requirements of tourists that stem from those changes are the macroenvironmental socio-demographic factors with greatest impact on the tourism environment. The experts believe that the main reasons to invest in innovation and ICT can be put down to the emergence of new market segments $(31.3 \%)$, the growth in Internet use $(25 \%)$, customers' new expectations and needs $(12.5 \%)$ and the increase in the number of trips with shorter than average lengths of stay $(12.5 \%)$. These all encourage ongoing innovation in hotels' products and production processes. The negative aspects limiting investments are related to last-minute purchasing by tourists $(6.3 \%)$ and the price wars initiated by many hotels in their Internet distribution channels as a policy to attract customers $(6.3 \%)$.

However, the Internet is not the only technology causing major changes in hotel management. The continual evolution of new technologies applicable to the hotel sector is a fundamental driving force of investment in ICTs. In 
particular, $30.8 \%$ of the experts' responses considered software and hardware development, and especially the appearance of such tools as Y\&RM and CRM (customer relations management), to be of major importance as part of the strategies of hotels located in the MAC. The increased market penetration of broadband Internet access $(15.4 \%)$, coupled with greater competition among the providers of the service $(7.7 \%)$ and the growth of mobile technology $(7.7 \%)$, make it easy for both hotels and their customers to access the Internet, and thus represent factors that encourage investment in these channels of communication. Lastly, there is the so-called 'demonstration effect' $(7.7 \%)$, in which hotels happily take up new technologies and innovations as a 'follower' sector rather than a 'leader'. The negative aspect in the technological category is related to the lack of importance that generating economies of scale might have in lowering production costs $(15.4 \%)$.

With respect to the political and legal conditions, the factor noted most frequently by the experts was the importance of the subsidies granted by public administrations $(18.8 \%)$ as an instrument of motivation for innovation and ICT investment. The other aspects were related to labour market conditions (immigration, increased social costs), environmental/ecological issues favouring the use of innovations and ICT to improve productive efficiency and intellectual property laws aimed at introducing charges for the transmission of knowledge and information via the Internet and TV, which would act as a disincentive for ICT investment by raising the cost of using this type of technology.

All the factors analysed in the present study have had a major influence on the recent growth of tourism in the MAC. It is clear, however, that the changes which are contributing decisively to the region's consolidation as a destination with great potential are those related to its new infrastructure. According to the experts $(50 \%)$, improvements in transportation and entry gateways, especially the new Terminal 4 at Madrid Barajas Airport and the rapid growth of low-cost carriers, are making it easy for clients to reach Madrid from new places of origin, and are thus naturally stimulating innovation. Other infrastructure, such as hospitals, golf courses and amusement parks, is attracting new market segments $(16.7 \%)$. This is also the case with the Madrid capital, whose 'music concert tourism' has been attracting thousands of people from other provinces every weekend. As negative aspects, the experts point to the slowness of change in culture and consumption habits (8.3\%) affecting some categories of clients.

Finally, the sole macroenvironment factor recognized as having a clear overall negative impact on hotels' innovation and ICT decisions is that of the condition of human resources. In this category, only two aspects were considered as positive for innovation - increased worker training $(11.1 \%)$ and the outsourcing of certain processes $(11.1 \%)$, which allows cost savings in certain areas (cleaning, security and marketing) and the professionalization of certain tasks. The rest of the aspects - especially poorly qualified workers $(33.3 \%)$ with a low level of foreign language skills (11.1\%), and in many instances with a lack of continuing education $(11.1 \%)$ - have a negative impact on the implementation of innovations and ICTs.

Although related closely to the infrastructure factors, the environmental/ ecological conditions are not mentioned by all the experts. Nonetheless, 50\% of the responses point to the negative impact that some of these factors 
(specifically, global warming and increasing environmental legislation) have on innovation and ICT investment strategies in the region's hotels. Indeed, whereas a certain level of increased environmental legislation together with the new demands of their customers stimulates hotels to innovate to adapt to those changes, excessively restrictive legislation causes them to attempt to do the bare minimum to comply, and to reduce their innovations in other areas. Other factors encouraging innovation are noise pollution, lack of water and tourists' demands for sustainable and responsible tourism.

\section{Microenvironment}

With respect to the microenvironment, the absence of entry barriers in the MAC hotel market favours increased competitive pressure. According to the experts, the MAC's tourism firms need to be aware that other destinations, with identical offer and more affordable prices, are in competition with Spanish hotel products. They also note $(28.6 \%)$ that foreign hotel chains are very likely to enter the Spanish market by acquisitions of existing hotels or by creating new establishments. The addition of new hotel products is also increasing competitiveness through, for instance, the appearance of low-cost establishments (14.3\%). These establishments provide a good quality-to-price ratio by offering accommodation services with no extras. Those already operating in Madrid include Spanish chains such as Room Mate and foreign chains such as easyHotel of the easyJet Group.

The Internet plays a fundamental role in determining the bargaining power of customers and intermediaries. For customers, Internet tools for transmitting and retrieving information (12.5\%), online purchases (e-commerce) $(12.5 \%)$ and increasing competition between buyers and suppliers $(25 \%)$ have all stimulated hotels to invest to improve their positioning in these channels of distribution. However, the bargaining power of intermediaries has been declining due to the increase in the direct contracting of hotel products (37.5\%). Many of them have decided to specialize, favouring the individual tailoring of hotel products and a reduction in retailers' commissions. As a reaction to this loss of power, certain tour operators are opting for mergers with large tourism corporations (25\%), with the result that hotels are losing market power and control over their own customers.

Finally, the emergence of substitute products is generating a major negative impact in discouraging investment in innovation. For example, the evolution of videoconferencing technology $(16.7 \%)$ can make some business trips unnecessary when there is a need for face-to-face contact with suppliers, customers or employees. There also stand out such new market segments as second residences $(33.3 \%)$, small hotels, apartments for rent and condominiums $(33.3 \%)$, and improved infrastructure and communications with cities bordering the region (16.7\%), all of which increase competition in the MAC's hotel market. The result is a mixture of positive and negative consequences with respect to stimulating innovation and ICT investment.

In sum, the present results allow one to identify the fundamental variables to consider in analysing the MAC's hotel market and its propensity for innovation. These are: increased competitiveness, changes in tourists' consumption habits, the growth of the Internet and human resources training. 
The results also provide partial support for the working hypothesis with which we began the study - that increased competition and the emergence of new customer needs stimulate hotels' investment in innovation and ICTs. While new customer needs clearly foster investment, increased competition has different effects on different hotels. While many of them have opted for innovation as the way to position themselves in a more competitive environment, others have adopted a wait-and-see response to the reduction in their profitability, foregoing innovation at least for the time being.

\section{Conclusions}

The present results have shown that, for hotels located in the MAC, technological development itself, new customer needs and increased competition are the main driving forces behind investment in innovation and ICT.

With respect to competition, while in all cases it is seen as having a major impact on hotels' investment in innovation, this impact is not always positive. ${ }^{1}$ The results show further that increased competition in the hotel sector is positive up to a certain point. When the milieu becomes too competitive, the choice is to divest from this sector to invest in others that are more profitable. This represents a major constraint on innovation and ICT investment strategies in this sector.

In the period 2000-2005 there was a notable increase in the competitive capacity of the MAC's hotels, although not as great as in the rest of the country. While the number of tourists visiting Madrid has been growing year by year, the total number of overnight stays has remained stable, while the number of hotels and rooms available has grown faster than the demand, especially in the higher category hotels. This situation has led to an improvement in supply, together with hotels' development of competitive strategies aimed at continuing to gain market share. Some hotels have opted for strategies of differentiation, improving the quality of services, adapting their product portfolio to customer needs - in sum, innovating. Others, however, have chosen a wait-and-see strategy in response to the decline in their profitability margins. Instead, they have decided to invest in more profitable economic activities while waiting for the current economic situation to change.

The impact of the new conditions of their milieu is clearly stimulating these hotels' innovation and ICT investments (80\% for factors of the new economic context and $75 \%$ for factors of the new socio-demographic conditions), although it is true that certain factors are more influential than others.

Improvements in transportation and entry gateways, the growth of low-cost carriers, the emergence of new market segments, the rapid evolution of software and hardware - in particular, of such tools as Y\&RM and CRM - and the increasing use of the Internet are the macroenvironment factors that the experts believe to have the greatest positive influence on the innovation and ICT investment behaviour of hotels. On the contrary, the main factors limiting these investments are the ever more restrictive environmental legislation and the lack of qualified personnel with whom to implement new technologies.

One of the factors driving tourism firms to innovate is the process of continual change characterizing the evolution of demand in the sector, with the 
consequent emergence of new market segments, and therefore of new sources of business. Such innovation needs to be preceded, however, by a greater capacity to generate knowledge about the behaviour of their markets. This capacity can even become a mechanism for generating competitive advantage (Fesenmaier et al, 1999; Gretzel and Fesenmaier, 2004; Buhalis and Law, 2008). This is an area in which much remains to be done (Buhalis and Law, 2008; Figueroa et al, 2009), especially with regard to understanding consumer behaviour patterns involving the Internet, the influence of social networks, etc. The joint public and private sector commitment to implementing 'knowledgebased tourism marketing information systems' could be a solution to this need.

The experts note that the Internet has contradictory effects on investment in innovation. Customers readily obtain information from the Internet and thus possess more knowledge about pricing strategies which, combined with increasing competition, leads some hotels to adopt short-term price reduction strategies, resulting in the typical open price war aimed at capturing clients. Nonetheless, the overall impact of the Internet is clearly positive since it encourages hotels to invest in innovation in order to adapt and seek competitive advantages in response to the emergence of new market segments and changing customer needs.

It is troubling, however, that firms could find their innovation processes slowed down due to a lack of trained personnel to meet these changes. In general, tourism often lags far behind other sectors with respect to the qualification of its human resources (excessive turnover, greater instability, mobility, low-quality job contracts, etc). Indeed, in the case of Spain, the low level of professionalization of the personnel employed in the tourism sector has long been recognized by all those involved in the sector as an as yet unresolved defect (Pearce, 1996; Vera and Marchena, 1996; Mariscal and Marchena, 2006), and one which has been putting a brake on tourism firms' gains in competitiveness. Innovation is linked to improved productivity and the qualification of human resources. It is therefore imperative for there to be greater political and entrepreneurial involvement in this area to ensure substantial improvement in the level of professionalism of workers in this sector in Spain. This undoubtedly will contribute to the current plan - in the framework of the Treaty of Bologna - for there to be university education in tourism at the highest level and thus leave behind a long period in which tourism studies have always been at a lower level.

In positive contrast, the importance the experts gave to political action in favour of innovation stands out as having been one of the key factors behind the decision of the MAC's hotels to invest in innovation and ICT. Tourism generally is ignored in national and regional innovation policies. This is partly because of a misperception that it has only a limited value creation capacity, and partly because the weakness and fragmentation of the industry itself limits its influence on the priorities of political agendas (Hall and Williams, 2008). The present results show, however, the interest of the tourism sector in implementing specific innovation policies, since they will contribute to improving the competitive positioning of the firms involved, and hence, of course, of the tourist destination itself.

The microenvironment factors that stimulate innovation and ICT investment are: the existence of other destinations with an identical but cheaper offer; the 
exit of intermediaries from the market, leading to a greater proportion of direct purchases; hotels' loss of market power and control over their own customers due to the merging of tour operators into large tourism corporations; increasing competition among hotels and suppliers; and the entry of foreign chains via acquisitions of existing hotels or the creation of new establishments.

However, in the microenvironment too there are negative factors limiting the investment behaviour of these hotels. These factors basically revolve around the threat generated by the existence of substitute products - the consolidation of the growing demand for a second residence and the existence of small hotels, rental apartments and condominiums.

We have seen therefore that, overall, the milieu the MAC hotels are operating in is fostering innovation in their sector, with macroenvironment factors having a more positive impact than those of the microenvironment.

\section{Endnotes}

1. A similar conclusion was drawn by Sancho (2004) for hotels in the province of Valencia, where the sign of the parameter indicated that high levels of competition did not encourage innovation in the hotel sector.

\section{References}

Aguilar, F.J. (1967), Scanning the Business Environment, Macmillan, New York.

Aydalot, P. (1986), Milieux innovateurs en Europe, Economica, Paris.

Buhalis, D. (1998), 'Strategic use of information technologies in the tourism industry', Tourism Management, Vol 19, No 5, pp 409-421.

Buhalis, D. (2005), 'Information technology in tourism', in Cooper, C., Fletcher, J., Fyall, A., Gilbert, D., and Wanhill, S., eds, Tourism. Principles and Practice, Prentice Hall, Harlow, pp 702736.

Buhalis, D., and Law, R. (2008), 'Progress in tourism management: twenty years on and 10 years after the Internet: the state of eTourism research', Tourism Management, Vol 29, No 4, pp 609623.

Buhalis, D., and Licata, M.C. (2002), 'The future of tourism intermediaries', Tourism Management, Vol 23, No 3, pp 207-220.

Camisón, C. (2000), 'Strategic attitudes and information technologies in the hospitality business: an empirical analysis', International Journal of Hospitality Management, Vol 19, No 2, pp 125-143.

Dwyer, L., Edwards, D., Mistilis, N., Roman, C., and Scott, N. (2009), 'Destination and enterprise management for a tourism future', Tourism Management, Vol 30, No 1, pp 63-74.

Ellyard, P. (2006), Societal Changes - Impacts and Opportunities for Tourism, Tourism Futures Conference, 21st Century Responses to 21st Century Realities, 4-6 December, Melbourne.

Fesenmaier, D., Leppers, A.W., and O'Leary, J. (1999), 'Developing a knowledge-based tourism marketing information system', Journal of Information Technology and Tourism, Vol 2, No 1, pp 3144.

Figueroa, C., Sáez, A., and Pulido, J.I. (2009), Impacto de la innovación y el cambio tecnológico en el sector botelero en destinos urbanos emergentes. El caso de la Comunidad de Madrid, Editorial Centro de Estudios Ramón Areces, SA, Madrid.

Figuerola, M. (2006), 'El modelo turístico español. Déficit, retos y oportunidades', in Sáez, A., Martín, P., and Pulido, J.I., coords, Estructura Económica del Turismo, Síntesis, Madrid, pp 369416.

Garrigós, F., and Narangajavana, Y. (2002), 'El proceso de globalización de la industria hotelera española: una visión retrospectiva de las cadenas españolas en la década de los noventa', Estudios Turísticos, Vol 152, pp 33-63.

Garrigós, F.J., Palacios, D., and Devece, C. (2004), 'TI y desempeño empresarial: un estudio en el sector hotelero español', Cuadernos de Economía y Dirección de la Empresa (http://www.acede.org/ index_archivos/CDMurcia/Indice\%20de\%20Autores/documentos/IdP240.pdf, accessed 14 August 2005). 
Gretzel, U., and Fesenmaier, D. (2004), 'Implementing a knowledge-based tourism marketing information system: the Illinois Tourism Network', Journal of Information Technology and Tourism, Vol 6, No 2, pp 245-255.

Grundy, T. (2006), 'Rethinking and reinventing Michael Porter's five forces model', Strategic Change, Vol 15, No 5, pp 213-229.

Guía, J., Prats, Ll., and Comas, J. (2006), 'The destination as a local system of innovation: the role of relational networks', in Lazzereti, L., and Petrillo, C.S., eds, Tourism Local Systems and Networking, Elsevier, London, pp 57-65.

Hall, M., and Williams, A.M. (2008), Tourism and Innovation, Routledge, New York.

Hansen, G.S., and Wernerfelt, B. (1989), 'Determinants of firm performance: the relative importance of economic and organizational factors', Strategic Management Journal, Vol 10, No 5, pp 399-411.

Instituto Nacional de Estadística (2008), 'Encuesta de Ocupación Hotelera 2007' (http://www.ine.es, accessed 14 May 2008).

ITH (Instituto Tecnológico Hotelero) (2007), El Proceso de Innovación en las Empresas del Sector Hotelero, Instituto Tecnológico Hotelero, Madrid.

Jacob, M., and Bravo, A. (2001), Estudio Exploratorio sobre la Innovación en el Sector Turístico Balear, Fundación COTEC, Madrid.

Johnson, G., and Scholes, K. (2002), Exploring Corporate Strategy: Text and Cases, Prentice Hall, Essex.

Karmarkar, U. (2004), 'Will you survive the services revolution?', Harvard Business Review, Vol 75, pp 102-113.

Mc $\overline{G a h a n, ~ A . M ., ~ a n d ~ P o r t e r, ~ M . ~(1997), ~ ' H o w ~ m u c h ~ d o e s ~ i n d u s t r y ~ m a t t e r, ~ r e a l l y ? ', ~ S t r a t e g i c ~ M a n-~}$ agement Journal, Vol 18, No S1, pp 15-30.

Maillat, D., and Perrin, J.C., eds (1992), Enterprises Innovatrices et Développement Territorial, EDES, Neuchâtel.

Marín, M.B., and Marín, G.M. (2002), 'Innovaciones tecnológicas en la gestión de reservas hoteleras', Revista Madrid, Vol 12 (http://www.madrimasd.org/revista/revista12/tribuna/tribunas5.asp, accessed 14 May 2005).

Mariscal, A., and Marchena, M. (2006), 'Turismo, mercado de trabajo e innovación', in Sáez, A., Martín, P., and Pulido, J.I., coords, Estructura Económica del Turismo, Síntesis, Madrid, pp 141175.

Mintzberg, H. (1987), La estructuración de las organizaciones, Ariel, Barcelona.

Monfort Mir, V.M. (2000), Competitividad y factores críticos de éxito en la 'botelería de litoral', FITUR, Madrid.

Namasivayam, K., Enz, C.A., and Siguaw, J.A. (2000), 'How wired are we? Selection and use of new technology in US hotels', Cornell Hotel and Restaurant Administration Quarterly, Vol 41, No 6, pp 40-48.

Olsen, M.D., and Connolly, D.J. (2000), 'Experience-based travel', Cornell Hotel and Restaurant Administration Quarterly, Vol 41, No 1, pp 30-40.

Pearce, D. (1996), 'Regional tourist organizations in Spain: emergence, policies and consequences', Tourism Economics, Vol 2, No 2, pp 119-136.

Porter, M.E. (1980), Competitive Strategy: Techniques for Analysing Industries and Competitors, Free Press, New York.

Porter, M.E. (1985), Competitive Advantage, Free Press, New York.

Porter, M.E. (1991), The Competitive Advantage of Nations, Free Press, New York.

Porter, M. (1996), 'What is strategy?', Harvard Business Review, November-December, pp 61-78.

Porter, M.E., and Montgomery, C.A. (1990), Strategy: Seeking and Securing Competitive Advantage, Harvard Business School Press, Boston.

Quinn, J.B. (1980), Strategies for Change: Logical Incrementalism, The Irwin Series in Management and the Behavioral Sciences, R.D. Irwin, Boston, MA.

Roquebert, J.A., Phillips, R.L., and Westfall, A. (1996), 'Markets vs management: what drives' profitability', Strategic Management Journal, Vol 17, No 3, pp 664-679.

Rumelt, R.P., Schendel, D., and Teece, D.J. (1991), 'Strategic management and economics', Strategic Management Journal, Vol 12, pp 5-29.

Sahadev, S., and Islam, N. (2005), 'Why hotels adopt ICTs: a study on the ICT adoption propensity of hotels in Thailand', International Journal of Contemporary Hospitality Management, Vol 17, No 5, pp 391-401.

Sancho, A. (2004), 'Innovación, especialización, diversidad y competitividad en el sector turístico de la Comunidad Valenciana' (http://www.uv.es/sancho/generalitati+d.pdf, accessed 15 January 2006). 
Sancho, A., and Maset, A. (2002), 'Tecnología y nada más: un mal negocio para las empresas turísticas' (http://www.turismo.uma.es/turitec/turitec2002/actas/Microsoft\%20Word\%20\%2029.SANCHOCASTELLON.pdf, accessed 30 November 2002).

Schmalense, R. (1985), 'Do markets differ much?', American Economic Review, Vol 75, No 3, pp 341351.

Sheldon, P. (2007), 'Tourism information technology', in Dwyer, L., and Forsyth, D., eds, International Handbook on the Economy of Tourism, Edward Elgar, Cheltelham.

Sigala, M. (2003), 'The information and communication technologies productivity impact on the UK hotel sector', International Journal of Operations and Production Management, Vol 23, No 10, pp $1224-1245$.

Siguaw, J.A. (2000), 'Adoption of information technologies in US hotels: strategically driven objectives', Journal of Travel Research, Vol 39, No 2, pp 192-201.

Simon, T., and Namasivayam, K. (1999), 'The eye of the beholder: hotel company CEO perceptions of threats and opportunities', Journal of Hospitality and Tourism Research, Vol 23, No 4, pp 354370 .

Vázquez Barquero, A. (2002), Endogenous Development, Networking, Innovation, Institutions and Cities, Routledge, London.

Vázquez Barquero, A., Alfonso, J., Sáez, A., and Viñas, A.I. (1999), SME Policy and the Regional Dimension of Innovation: The Spanish Report of SMEPOL, No 6, European Commission, Brussels.

Vera, J.F., and Marchena, M. (1996), 'El modelo turístico español: perspectiva económica y territorial', in Pedreño, A., dir, Introducción a la economía del turismo en España, Civitas, Madrid, pp 327-364.

Victorino, L., Verma, R., Plaschka, G., and Chekitan, D. (2005), 'Service innovation and customer choices in the hospitality industry', Managing Services Quality, Vol 155, pp 555-576.

Wei, S., Ruys, H.F., Van Hoof, H.B., and Combrink, T.E. (2001), 'Uses of the Internet in the global hotel industry', Journal of Business Research, Vol 54, No 3, pp 235-241. 